\title{
The Importance of Modern Pharmacy Marketing to Conquer New Markets Through Electronic Pharmacy
}

\author{
IGNJATOVIC Dejana1, COGOLJEVIC Maja² \\ ${ }^{1}$ University Sinergija, Bijeljina, Republika Srpska, (SERBIA) \\ ${ }^{2}$ Faculty of business economy and entrepreneursip, Belgrade, (SERBIA) \\ Emails:dejanaignjatovic9@gmail.com,maja.cogoljevic@vspep.edu.rs
}

\begin{abstract}
The role of pharmacies has changed during the last decades of the $20^{\text {th }}$ century within both the societal and medical spheres. From a place manufacturing medicine, to procurement and distribution of medicine, pharmacies became modern medical facilities that participate in the medical system and retail pharmaceutical market. The duality of the role of pharmacy requires adjustments to the demands of healthcare policies and contemporary market principles. The implementation of contemporary business practices, such as marketing, was mostly absent until recently. This research focuses on the use of internet for pharmaceutical marketing and the possible application of online pharmacies in Republika Srpska. Pharmaceutical workers, the respondents of the questionnaire, point to the possibilities that the implementation of online business presents and all the strengths and weaknesses of such a manner of operation.

From this, it is concluded that the implementation of electronic pharmacies would lead to the improvement of economic results for pharmaceutical establishments within Republika Srpska and $\mathrm{BiH}$.
\end{abstract}

Keywords: pharmacy, online pharmacy, marketing, new markets, electronic trade, promotion

JEL: M31

UDK: 658.8:615

004.738.5:339.13

\section{Introduction}

Pharmaceutical business is of general and specific social interest, because it directly contributes to the betterment and protection of people's health. It encompasses production, control, distribution, prescription and sale of pharmaceutical products, but it also offers different healthcare services that are aimed at bettering the quality of lives for the general public. Accordingly, pharmaceutical marketing encompasses both general and specific knowledge related to products of services in the spheres of medicine, therapy and health betterment. Thus, the concepts of pharmaceutical products marketing and pharmaceutical services marketing are regarded as separate, when in reality they indivisible.

The main hypothesis of the research: Use of digital marketing and contemporary forms of electronic business in pharmacy would greatly benefit the turnover of products in pharmacies in Republika Srpska. The aim of this research is, on the basis of domestic and foreign references and the discoveries that came through them, to inform the public about different technologies and models of e-trade in pharmacy, and to determine the importance of electronic marketing and the implementation of electronic models of business for the advancement of pharmaceutical business. The social aim of this research is to offer new information and discoveries to all those 
who are employed in pharmaceutics and wish to involve themselves in electronic trade and marketing, so that their pharmacy could be competitive on the market. The results of the research will confirm the importance of new technologies in pharmaceutics for the improvement of business transactions and making pharmaceutical products more available. A survey was conducted on the territory of Republika Srpska during the month of September, 2019. The information about the attitude of employees in the pharmaceutical business was collected using a questionnaire in one hundred pharmacies the territory of Republika Srpska, where the respondents had the ability to state their views on the importance of implementing forms of electronic business in pharmacy. The questionnaire was distributed both by hand and by email to one hundred and eighty respondents, of which one hundred answered. The questionnaire is made up of nine questions, three of which relate to general characteristics of the respondents, while six of them pertain to the subject and the hypothesis of the research. The research was conducted using a survey questionnaire. During the research, the methods of synthesis, analysis and description were used. The research was comprised of a stratified sample of one hundred respondents on the territory of Republika Srpska, and was conducted during the month of September, 2019. It is expected that the research will confirm the hypothesis, to prove that the electronic business method would improve the work of pharmacies and that this method would make the products more available to the general public which would lead to the increase in profit.

\section{Literature Review}

Pharmaceutical marketing is a very intensive discipline which encompasses both general and specific knowledge of marketing and business activities connected to the product/service in the sphere of medicine, therapy, improvement of the health of patients/citizens/buyers, with profits going to the society and organization which provides the product/service (economy and healthcare).

With the adequate infrastructure for e-business, technology is a second major prerequisite for the realization of efficient e-business activities and operations in pharmacy. In a contemporary environment, every company is faced with dynamic conditions of business and greater requirements for information systems that can fill the unexpected needs of managers for new information [1]. There is no ideal technology, that is, there exist no technology that gives the best results in every organization and every business situation [2]. Electronic pharmacy can be defined as a process of buying, selling, transfer or exchange of pharmaceutical products, services or information on a computer network, including the internet [3]. Distribution of prescribed pharmaceutical products on the internet poses serious legal and regulatory questions, including which methods the governments, agencies or organizations will use to oversee and regulate such activities [4]. Online distribution of medicine is globally increasingly present, and its results will be quantifiable in the coming decades. Current experience points to the lack of professional oversight of the distribution of "for health" products, which has led to numerous life-threatening consequences [5].

Nevertheless, the trend towards more liberal markets has made an impact on the pharmaceutical market as well. In $\mathrm{BiH}$, only pharmacies have the license to sell medicine. Significant advancements were made in regards to availability and variety of services, mostly through the use of the advancements of information technology.

Pharmaceutical marketing is specific in that medicine and medical products have a specific use and are not available to everyone, but only to those who have a doctor's prescription or are advised by their pharmacist [6]. At the same time, these products are responsible for people's health, thus they are subject to a strict and special legislation on their way to the market, starting from regulation during manufacturing, quality control, distribution, a premarketing phase, 
registration procedure - marketing license to the post-marketing phase of tracking the medicine. There is an emphasis on social responsibility because the pharmaceutical industry is a part of the healthcare system, and the goal of making a profit is intrinsically linked to the economic power of the population and the health insurance system.

Advertising OTC medicine should encourage rational use of the medicine, presenting it objectively and without the overemphasizing its properties, and should not be wrong or misinforming. Here, OTC products are available in public pharmacies, so the pharmacist is the primary promoter of this kind of medicine to the population that is asking them for advice and medicine for milder aliments. In European countries and the rest of the world, however, this type of medicine is allowed to be sold outside of pharmacies, in places such as supermarkets or gas stations, so they are available to the general population without any oversight. Erroneous use of medicine, a large number of interactions (particularly of herbal products with conventional medicine, which are often overlooked), manifestation of side effects, create a sick nation. Medicine must stay in pharmacies, even if it is a herbal medicine, or a multivitamin products in effervescent pills (it is not a substance like juice, that can be drank without limit), because only highly educated individuals, such as the staff of pharmacies, can give the public correct information as to how, how long and in what combination with other products can the medicine be used.

\section{Research Results and Discussion}

Out of 100 respondents that answered the questions, $70 \%$ were female while $30 \%$ were male. As far as qualification is concerned, $61 \%$ of respondents have a university degree, while $39 \%$ have a high school degree. Within Table 1., the first column represents questions to which the respondents gave answers to, while the rest are their responses. For transparency, answers to the last two questions were marked with letters a-d (A-D) in concurrence with Likert scale:

a) I consider myself very informed

b) I consider myself averagely informed

c) I consider myself not informed enough

d) I consider myself unaware

A) I have no possibility of quality control

B) I cannot get a refund

C) The delivery is slow

D) Safety systems are inadequate

Table 1. Respondents answers

\begin{tabular}{|c|c|c|c|c|}
\hline Question & YES & $\mathrm{NO}$ & & \\
\hline $\begin{array}{l}\text { Have you heard about the purchase of pharmaceutical } \\
\text { products on the internet? }\end{array}$ & $99 \%$ & $1 \%$ & & \\
\hline $\begin{array}{l}\text { Do you consider online purchases to be better than going to } \\
\text { the pharmacy? }\end{array}$ & $13 \%$ & $87 \%$ & & \\
\hline Do you shop over the internet? & $64 \%$ & $36 \%$ & & \\
\hline $\begin{array}{l}\text { If it were possible, would you buy medicine over the } \\
\text { internet? }\end{array}$ & $65 \%$ & $11 \%$ & $\begin{array}{l}* \text { after consulting a } \\
\text { pharmacist } 24 \%\end{array}$ & \\
\hline $\begin{array}{l}\text { Do you consider yourself informed about the potentials, } \\
\text { advantages and disadvantages of online purchasing of } \\
\text { pharmaceutical products? }\end{array}$ & $\begin{array}{l}\mathrm{a}: \\
18 \%\end{array}$ & $\begin{array}{c}\text { b: } \\
29 \%\end{array}$ & c: $26 \%$ & $\begin{array}{c}\mathrm{d}: \\
27 \%\end{array}$ \\
\hline $\begin{array}{l}\text { What do you consider to be the main drawback of online } \\
\text { purchasing of pharmaceutical products? }\end{array}$ & $\begin{array}{c}\text { A: } \\
32 \%\end{array}$ & $\begin{array}{c}\mathrm{B}: \\
24 \%\end{array}$ & C: $25 \%$ & $\begin{array}{c}\mathrm{D}: \\
19 \%\end{array}$ \\
\hline
\end{tabular}

Source: Author's calculation

From all of the respondents, $99 \%$ of them have heard about online purchasing, while $1 \%$ did not. Also, $13 \%$ said that that purchasing on the internet is better, while $87 \%$ said that it is not. 
Answering the question whether they shop for regular non-pharmaceutical products online, $64 \%$ of respondents said that they do, while $36 \%$ said that they do not. This illustrates that there is potential for the growth of online sales, as well as the growing influence of globalization on the "e-market". If it were possible, with regards to the current legislation in Republika Srpska, $65 \%$ of respondents said that they would buy medicine online, but only after consulting a pharmacist, while $24 \%$ said that they would not buy medicine online. From all of the respondents, $18 \%$ said that they are completely unaware of the possibilities, advantages and disadvantages of online purchasing, $27 \%$ said that they are very informed, 26\% said that they are averagely informed, while $29 \%$ said that they are not informed enough about the possibilities, advantages and disadvantages of online purchasing of pharmaceutical products. When asked about the main drawbacks of online purchasing of pharmaceutical products, $32 \%$ of the respondents said it is a lack of adequate security systems, $25 \%$ said the inability to get a refund, 24\% said slow delivery, and 19\% said the inability to check the quality of the products. Linking the results with the hypothesis it can be concluded that the hypothesis is confirmed, because the results show that most of the respondents, who are pharmaceutical workers themselves, would buy medicine on the internet, rather than going to the pharmacy. Although, it is important to note that all of them consider that a consultation with a pharmacist is necessary. It is without a doubt that online purchasing has its advantages, but also disadvantages, that the respondents were keen on emphasizing.

\section{Conclusion}

Research shows a decrease in the number of active web locations of internet pharmacies, the exchange of medical information is usually inefficient; information about medicine is not properly displayed and the contents of instructions are usually incomplete. Many network operators have been defined as illegal internet pharmacies, but among them were no legitimate internet pharmacies [7]. In a research that did a cross-section study of 275 web locations in English, found using Google.com and AltaVista.com for "prescription drugs", it was concluded that internet pharmacies that sell prescription medicine could be categorized into four kinds: (1) legal pharmacies; (2) subscription pharmacies; (3) lifestyle pharmacies; (4) pharmacies without prescription [8]. Evidence point to the fact that the customers are potentially exposed to risks when buying medicine online. Results also show that a great number of web locations sold medicine that they should not have, and that less than a quarter of all were regular online pharmacies. 80 web locations were ready to sell medication without prescription [9]. All of this points to serious problems that can arise during the implementation of electronic pharmacies, so a certain amount of distrust towards online pharmaceutical services is understandable. It, perhaps, is also a justified reason why the law in Bosnia and Herzegovina does not allow the sales of medicine on the internet. On the other hand, the positive effects of online sales of medicine has on pharmaceutical business, are justified economically.

\section{REFERENCES}

1. Nikolic M., Vesic T., Gavrilovic M. (2019). Značaj savremenih informacionih tehnologija za donošenje poslovnih odluka, Trendovi u poslovanju, Br. 13, Sv. 1/2019, pp. 31-36.

2. Punoševac M. (2011). Elektronska trgovina. Beograd: Poslovni fakultet Univerziteta Singidunum.

3. Balaban N. (2009). Informacione tehnologije. Novi Sad: Ekonomski fakultet Subotica.

4. Judith S., Carolyn S., Rosemary R. (2011). Selling drugs online: distribution-related legal/regulatory issues. International Marketing Review, 18(4), pp. 432-449.

5. Tomas-Miskin S., Vitomir J. (2019). Implementation of marketing in managerial functionsof banks, International Review No.3-4, 2019, pp. 101-109. 
6. Omidi F., Jorfi A., Jorfi F., Study of the Relationship Between Entrepreneurial Services and Competitive Benefits of the Staff of Ahwaz University of Medical Sciences with the Mediator Role of Interactive and Supportive Innovation, International Review No.3-4, 2018, pp. 60-72.

7. Fittler A., Bősze G., Botz L. (2013). Valuating Aspects of Online Medication Safety in Long-Term Follow-Up of 136 Internet Pharmacies: Illegal Rogue Online Pharmacies Flourish and Are Long-Lived. Journal of Medical Internet Research, 15 (9), pp. 199-209.

8. Littlejohn C., Baldacchino A., Schifano F., Deluca P. (2005). Internet pharmacies and online prescription drug sales: a cross-sectional study, Drugs: Education. Prevention and Policy, pp. 5-80.

9. Liang B., Mackey T., Lovett K. (2012). Suspect online sellers and contraceptive access. Contraception, 86(5), pp. 551-556.

\section{Article history:}

- Received 10 November 2019

- Accepted 15 December 2019 